\title{
The MUMBA campaign: measurements of urban, marine and biogenic air
}

\author{
Clare Paton-Walsh ${ }^{1}$, Élise-Andrée Guérette ${ }^{1}$, Dagmar Kubistin ${ }^{1}$, Ruhi Humphries ${ }^{1,2}$, \\ Stephen R. Wilson ${ }^{1}$, Doreena Dominick ${ }^{1}$, Ian Galbally ${ }^{1,2}$, Rebecca Buchholz ${ }^{1,3}$, Mahendra Bhujel ${ }^{1,2}$, \\ Scott Chambers $^{4}$, Min Cheng ${ }^{2}$, Martin Cope ${ }^{2}$, Perry Davy ${ }^{5}$, Kathryn Emmerson ${ }^{2}$, David W. T. Griffith ${ }^{1}$, \\ Alan Griffiths ${ }^{4}$, Melita Keywood ${ }^{2}$, Sarah Lawson ${ }^{2}$, Suzie Molloy ${ }^{2}$, Géraldine Rea ${ }^{1,6}$, Paul Selleck², \\ Xue Shi $^{1}$, Jack Simmons ${ }^{1}$, and Voltaire Velazco ${ }^{1}$ \\ ${ }^{1}$ Centre for Atmospheric Chemistry, School of Chemistry, University of Wollongong, Northfields Avenue, \\ Wollongong NSW, Australia \\ ${ }^{2}$ CSIRO Climate Science Centre, Aspendale Victoria, Australia \\ ${ }^{3}$ Atmospheric Chemistry Observations \& Modeling (ACOM) Laboratory, National Center for Atmospheric \\ Research, Boulder, CO, USA \\ ${ }^{4}$ ANSTO Institute for Environmental Research, Locked Bag 2001, Kirrawee DC NSW 2232, Australia \\ ${ }^{5}$ GNS Science, National Isotope Centre, Lower Hutt, New Zealand \\ ${ }^{6}$ Université Pierre et Marie Curie, Laboratoire de Météorologie Dynamique - CNRS/IPSL Ecole \\ Polytechnique, 91128 Palaiseau Cedex, Paris, France
}

Correspondence to: Clare Paton-Walsh (clarem@uow.edu.au)

Received: 16 February 2017 - Discussion started: 23 February 2017

Revised: 3 May 2017 - Accepted: 4 May 2017 - Published: 6 June 2017

\begin{abstract}
The Measurements of Urban, Marine and Biogenic Air (MUMBA) campaign took place in Wollongong, New South Wales (a small coastal city approximately $80 \mathrm{~km}$ south of Sydney, Australia) from 21 December 2012 to 15 February 2013. Like many Australian cities, Wollongong is surrounded by dense eucalyptus forest, so the urban airshed is heavily influenced by biogenic emissions. Instruments were deployed during MUMBA to measure the gaseous and aerosol composition of the atmosphere with the aim of providing a detailed characterisation of the complex environment of the ocean-forest-urban interface that could be used to test the skill of atmospheric models. The gases measured included ozone, oxides of nitrogen, carbon monoxide, carbon dioxide, methane and many of the most abundant volatile organic compounds. The aerosol characterisation included total particle counts above $3 \mathrm{~nm}$, total cloud condensation nuclei counts, mass concentration, number concentration size distribution, aerosol chemical analyses and elemental analysis.

The campaign captured varied meteorological conditions, including two extreme heat events, providing a potentially valuable test for models of future air quality in a warmer climate. There was also an episode when the site sampled clean marine air for many hours, providing a useful additional measure of the background concentrations of these trace gases within this poorly sampled region of the globe. In this paper we describe the campaign, the meteorology and the resulting observations of atmospheric composition in general terms in order to equip the reader with a sufficient understanding of the Wollongong regional influences to use the MUMBA datasets as a case study for testing a chemical transport model. The data are available from PANGAEA (http: //doi.pangaea.de/10.1594/PANGAEA.871982).
\end{abstract}




\section{Introduction}

The value of intensive measurement campaigns in helping to understand and characterise local atmospheric composition and air quality has been recognised since as early as 1969, when the Los Angeles Smog Project took place (Whitby et al., 1972b). Since then, many such campaigns have focused on understanding the formation of photochemical smog in the most polluted cities worldwide, with early efforts concentrated in the USA (e.g. Gray et al., 1986; Husar et al., 1972; Whitby et al., 1972a). The formation of secondary organic aerosol has also been of particular interest, with many studies using elemental carbon (black carbon) as an indicator of primary emissions; when the ratio of organic carbon to elemental carbon in the sampled air is higher than expected from the ratio of the primary emissions, secondary organic aerosol formation is indicated (Castro et al., 1999; Gray et al., 1986; Turpin and Huntzicker, 1995).

In Australia, there have been a number of studies aimed at improving our understanding of ozone chemistry in the cleaner Southern Hemisphere atmosphere (Galbally et al., 2000; Monks et al., 1998), secondary aerosol formation (Cainey et al., 2007) and other air quality issues, such as air toxins and smoke (Hinwood et al., 2007; Keywood et al., 2015). There have also been some air quality studies specifically aimed at testing the Australian Air Quality Forecasting System (Cope et al., 2004) in Sydney (Hess et al., 2004) and Melbourne (Tory et al., 2004). The primary focus of these studies was to test the prediction of ozone levels in the urban environment (Cope et al., 2005). More recent studies have examined regional air quality in Wollongong (Buchholz et al., 2016) and the effect of a major fire event on air quality in Sydney and Wollongong (Rea et al., 2016). There have also been Australian campaigns focused on understanding aerosol formation and composition in the urban environment, e.g. (Cheung et al., 2011, 2012) coastal environments (Cainey et al., 2007; Fletcher et al., 2007; Modini et al., 2009) and within eucalypt forests (Ristovski et al., 2010; Suni et al., 2008). In addition, there have been some detailed studies to characterise the concentrations of VOCs in the clean background atmosphere in the Australasian region (Colomb et al., 2009; Galbally et al., 2007; Lawson et al., 2015).

In this overview paper, we describe a measurement campaign in Wollongong, a small Australian coastal city with approximately 292000 residents. The Wollongong region is bounded by ocean to the east and by a steep escarpment covered in eucalypt forest to the west. The coastal plain is roughly triangular in shape, being very narrow in the north where the escarpment meets the sea and roughly $20 \mathrm{~km}$ wide in the south. The region spans about $50 \mathrm{~km}$ of coastline.

The MUMBA campaign involved collaboration between three Australian research groups: the University of Wollongong, the Commonwealth Scientific and Industrial Research Organisation (CSIRO) and the Australian Nuclear Science and Technology Organisation (ANSTO), as well as one research organisation from New Zealand (GNS Science). MUMBA was designed to provide a comprehensive characterisation of the local atmosphere that could test the capabilities of air quality models to forecast atmospheric composition. Influences from nearby ocean sources, urban emissions and the biogenic emissions from the surrounding eucalypt forests were expected to impact the site. This campaign aimed to make detailed measurements of atmospheric composition under the combined influence of these different sources, all of which typically affect the populated regions on the eastern coast of Australia.

\section{Measurement sites}

The MUMBA campaign included instruments that were run at several different nearby sites. The main measurement site $\left(34.397^{\circ} \mathrm{S}, 150.900^{\circ} \mathrm{E}\right)$ of the MUMBA campaign was located in a suburban area of Wollongong approximately $0.5 \mathrm{~km}$ from the ocean. The instruments were located in and adjacent to an unused hut located at the University of Wollongong's campus east (see Fig. 1a). Most of the instruments sampled from a mast at a height of $\sim 10 \mathrm{~m}$ above the surrounding ground level (also shown in Fig. 1a). Immediately surrounding the measurement site is a grassy plain with a suburban road to the east and a strip of forested parkland beyond, before the sand dunes and ocean. Prevailing easterly sea breezes brought air masses from the ocean to the site during the day. Urban influences from the local metropolitan area and a large industrial area, including a steelworks, typically occurred in still conditions or with southerly winds. The steelworks and surrounding industry is a large source of $\mathrm{PM}_{2.5}$ and $\mathrm{CO}$, whilst traffic dominates the remainder of the urban pollution sources. The steep forested escarpment is about $3 \mathrm{~km}$ directly to the west of the site and approximately $400 \mathrm{~m}$ high with the area beyond dominated by eucalypt forest, such that westerly winds brought strong biogenic signals. The population density within the surrounding area of New South Wales (NSW), including Wollongong and Sydney, is shown in Fig. $1 b$.

The locations of the different measurement sites are shown in Fig. 1c.

In addition, ANSTO provided measurements of atmospheric radon concentrations from Warrawong $\left(34.48^{\circ} \mathrm{S}\right.$, $150.89^{\circ} \mathrm{E}$ ), an industrial suburban site located approximately $10 \mathrm{~km}$ to the south of the main MUMBA site. The use of radon to characterise boundary layer mixing (Chambers et al., 2011) is likely to be especially useful for testing air quality models due to the challenges of modelling within the complex topography of coastal areas. The locations of all of the sites used in the MUMBA campaign are marked on the satellite view of the region shown in Fig. 1c. 

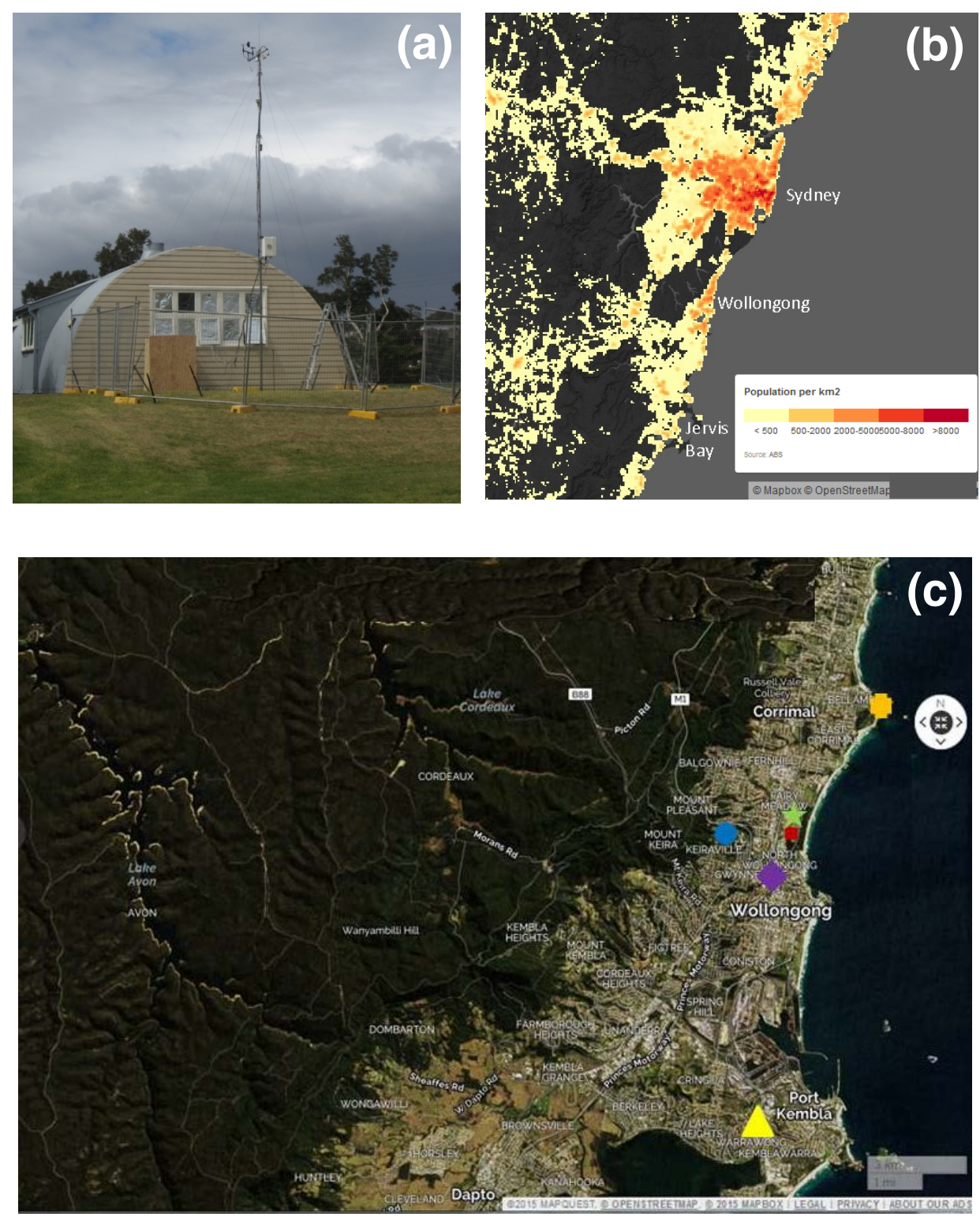

Figure 1. (a) The hut that housed most of the instruments during MUMBA and the sample mast. (b) A population density map for the region based on the Australian Bureau of Statistics data from August 2011 (http://www.abs.gov.au/AUSSTATS/abs@.nsf/Lookup/1270.0.55. 007Main+Features12011?OpenDocument) (c) A satellite view of the region showing the main MUMBA site (green star), the Wollongong Science Centre (red square), the Wollongong EPA air quality station (purple diamond), the University of Wollongong (blue circle), the Bellambi automatic weather station (orange hexagon) and the ANSTO radon detector site at Warrawong (yellow triangle). Also visible is the large industrial area at Port Kembla and the extensive forested regions to the west. The image was created using www.mapquest. com, OpenStreetMap contributors.

\section{Description of the instruments deployed at the main measurement site}

A large range of instrumentation was deployed to enable a detailed characterisation of atmospheric composition during the campaign. All measurements made during the campaign are listed in Table 1, along with the dates of operation for each instrument. MUMBA operated in two distinct stages with most gas-phase and meteorological measurements run- ning throughout the 8 week campaign and aerosol-phase measurements added in the second half of the campaign. A few instruments operated for different time periods, and these are distinguished in Table 1. All data are available from PANGAEA (https://doi.pangaea.de/10.1594/PANGAEA.871982) as hourly averages unless otherwise specified. Further details of the instruments are given in the Appendix along with a second table that lists the specific VOCs measured during the 


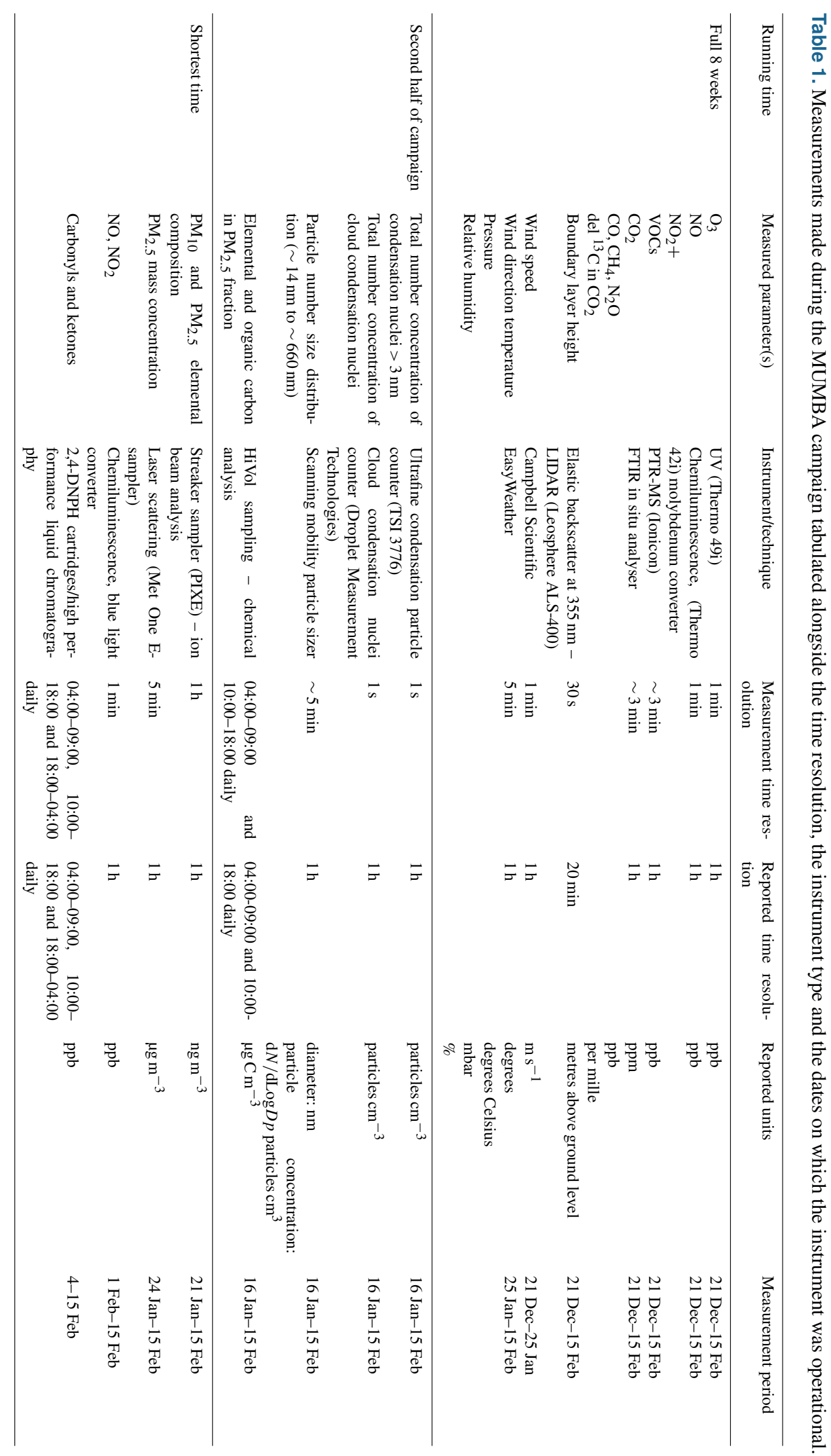


campaign and their limits of detection. Note that some instruments can produce negative values when the concentrations are close to the detection limit. Negative concentration values (although non-physical) have not been removed from the MUMBA dataset because they are indicative of the instruments' true performance; removing negative values will produce small positive biases in the calculations of longer-term average concentrations. Also available from PANGAEA are the radon measurements made at Warrawong by ANSTO and the air quality data from the Wollongong Office of Environment and Heritage (OEH) station. The FTIR spectrometer uses a drier on the inlet, and it measured the mole fraction in dry air; the other gas-phase instruments measured in ambient air. All measurements are reported in local standard time $(\mathrm{UTC}+10)$.

\section{Additional measurements}

Measurements were also available from the OEH air quality station at Wollongong $\left(34.419^{\circ} \mathrm{S}, 150.886^{\circ} \mathrm{E}\right)$. Additional instruments were operated nearby at the University of Wollongong's main campus (at $34.406^{\circ} \mathrm{S}, 150.897^{\circ} \mathrm{E}$ ) (Buchholz et al., 2016) and at the nearby Science Centre $\left(34.401^{\circ} \mathrm{S}, 150.900^{\circ} \mathrm{E}\right)$, but the observations are not included here. Data from the University of Wollongong include retrievals of total column amounts of trace gases from the Total Carbon Column Observing Network (http://www. tccon.caltech.edu/) and the Network for the Detection of Atmospheric Composition Change (http://www.ndsc.ncep. noaa.gov/) as well as in situ greenhouse gas measurements (http://doi.pangaea.de/10.1594/PANGAEA.848263). The instrument installed at the Science Centre was a multi-axis differential optical absorption spectrometer, and the data are available from the authors upon request. The Australian $\mathrm{Bu}-$ reau of Meteorology (BOM) operates an automatic weather station (AWS) at Bellambi $\left(34.37^{\circ} \mathrm{S}, 150.93^{\circ} \mathrm{E}\right)$. Again, the data are not included here but can be requested from the BOM if needed.

\section{Meteorology during the MUMBA campaign}

The summer of 2012-2013 was the hottest summer on record for Australia at the time (White and Fox-Hughes, 2013). There were two extremely hot days in the Wollongong region during MUMBA, with maximum temperatures of $40.4{ }^{\circ} \mathrm{C}$ on 8 January and $42.4^{\circ} \mathrm{C}$ on 18 January 2013 recorded at Bellambi AWS (both below the record of $43.7^{\circ} \mathrm{C}$ set on 1 January 2006). The campaign encompassed the wettest January day on record for the region, with $139 \mathrm{~mm}$ of rain falling at Bellambi AWS between 08:00 on 28 January and 08:00 on 29 January 2013 (see the top panel of Fig. 2).

The lower panel of Fig. 2 shows the mean hourly temperature recorded from the $10 \mathrm{~m}$ mast at the MUMBA site over the campaign. The two extremely hot days can be clearly
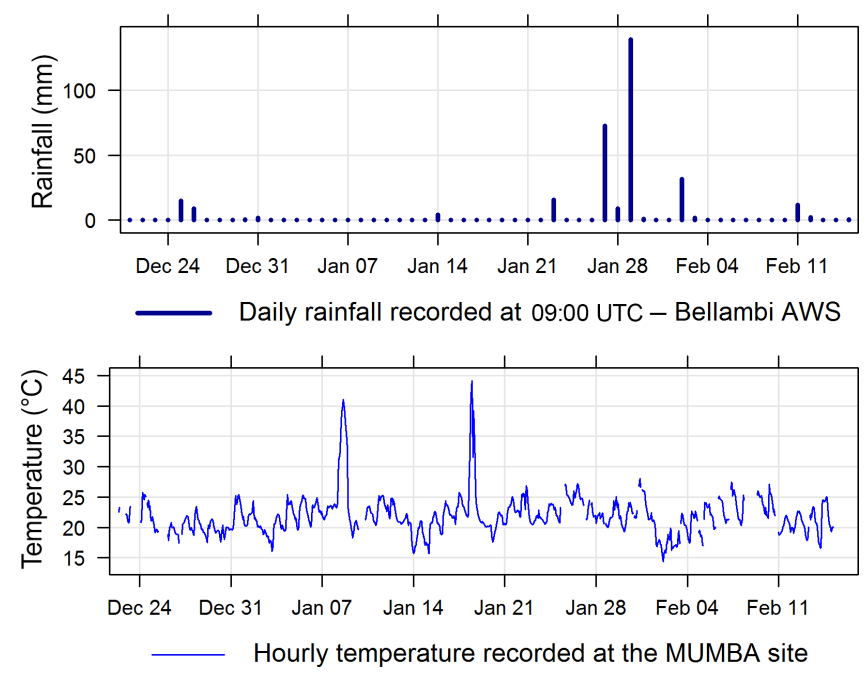

Figure 2. The upper panel shows a bar chart of daily rainfall in millimetres from Bellambi AWS. The lower panel shows the time series of the mean hourly temperature measured during MUMBA.

seen in this figure. The mean daily maximum temperature during January 2013 was $25.7^{\circ} \mathrm{C}$, which is $0.9^{\circ} \mathrm{C}$ above the long-term average of $24.8^{\circ} \mathrm{C}$ and in the 95th percentile of monthly mean maximum temperatures for January at Bellambi AWS (using data from 1988 to the present).

The average wind speed recorded at the MUMBA site during the campaign was $2.8 \mathrm{~ms}^{-1}$, and the maximum hourly averaged wind speed recorded was $9.2 \mathrm{~ms}^{-1}$. The $1 \mathrm{st}$, 2nd (median) and 3rd quartiles of the wind speed were 1.4, 2.6 and $3.9 \mathrm{~ms}^{-1}$ respectively. Figure 3 shows the composite diurnal cycles of the wind speed and wind direction as measured at the main MUMBA site. The general pattern was a relatively strong sea breeze during the day $(\sim$ easterly winds of 3-4 $\mathrm{ms}^{-1}$ ) and calmer conditions overnight. Westerly winds were more frequent during nighttime (although northeasterly winds sometimes persisted into the night). This pattern was repeated all over the local region (as shown in data from OEH air quality sites and from the University of Wollongong) (Guérette, 2016).

The third panel in Fig. 3 shows the composite diurnal cycle of radon measured at the ANSTO site in Warrawong. The radon plot shows a build-up at night with a peak in the early hours of the morning, indicating a shallower and more stable boundary layer at night than during the day, with the boundary layer at its shallowest around 05:00 or 06:00. During the day, due to heating at the surface and other processes, the boundary layer grows deeper and more turbulent; this is reflected in the lower radon values observed during the day. Minimum radon levels in the afternoon are also influenced by the fetch of the air reaching the site, with air that has travelled over the ocean containing less radon than air that has travelled over land (Chambers et al., 2015). In the Wollongong region, an increased boundary layer height and strong sea 

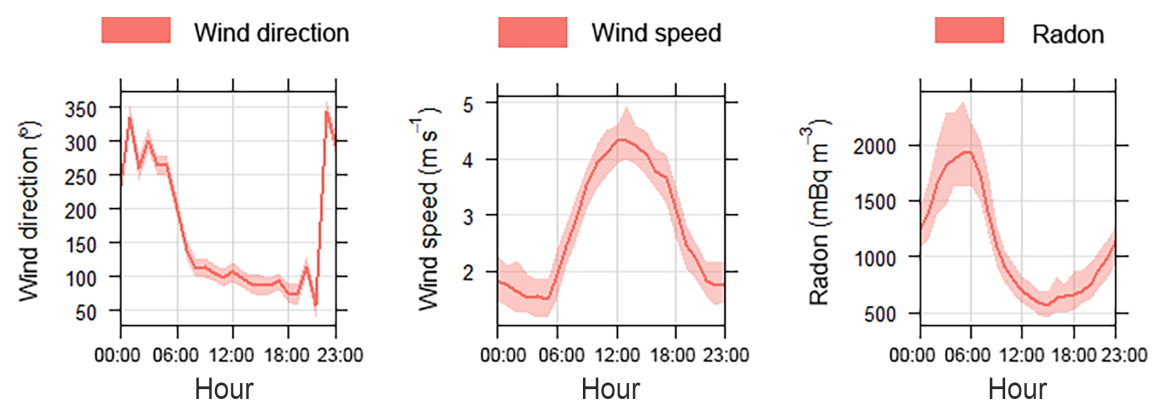

Figure 3. The observed diurnal cycles of the wind direction and wind speed at the main MUMBA site, and the radon concentration at Warrawong observed during the campaign. The shaded area shows a $95 \%$ confidence interval from a bootstrap resampling of the data. See Carslaw and Ropkins (2012) for a description of this and for calculations of the average wind direction.

breezes combine to produce the low radon levels observed in the afternoon.

Comparisons of the winds measured at the MUMBA site during the campaign to simultaneous measurements at the three air quality sites operated by the Office of Environment and Heritage in the area (at Wollongong, Kembla Grange and Albion Park) indicated that the wind patterns observed at the MUMBA site were generally representative of the region as a whole (Guérette, 2016). The long-term average wind data at 15:00 each day are publicly available from the Bellambi AWS from 1997-2010, and these were used for comparison with the wind data recorded at this time throughout January during the campaign. The MUMBA site in January 2013 was characterised by slightly less frequent northerly winds and slightly more frequent westerly winds than expected from the long-term average at Bellambi, but otherwise the wind patterns were very similar in the two records. The MUMBA site experienced lower wind speeds than the long-term averages at Bellambi (but this may be due to location differences rather than atypical weather patterns) (Guérette, 2016). Thus we conclude that the measurements made at the MUMBA site during the campaign should be broadly representative of the region as well as of the summer season.

On a larger scale, the dominant circulation pattern during MUMBA was anticyclonic with the main fetch being principally oceanic (as opposed to continental), which is typical of summer (Chambers et al., 2011). This is illustrated in Fig. 4, which shows a gridded back trajectory frequency plot for $96 \mathrm{~h}$ precalculated back trajectories made available for Wollongong through the openair package (Carslaw and Ropkins, 2012). The trajectories were calculated using the HYSPLIT trajectory model (Hybrid Single Particle Lagrangian Integrated Trajectory Model; http://ready.arl. noaa.gov/HYSPLIT.php) every $3 \mathrm{~h}$ from an initial height of $10 \mathrm{~m}$ and propagated backwards in time for $96 \mathrm{~h}$ using the global NOAA-NCEP/NCAR reanalysis meteorological fields at $2.5^{\circ}$ of horizontal resolution. The surface of the plot is coloured by the percentage of the total trajectories which pass through each grid box.

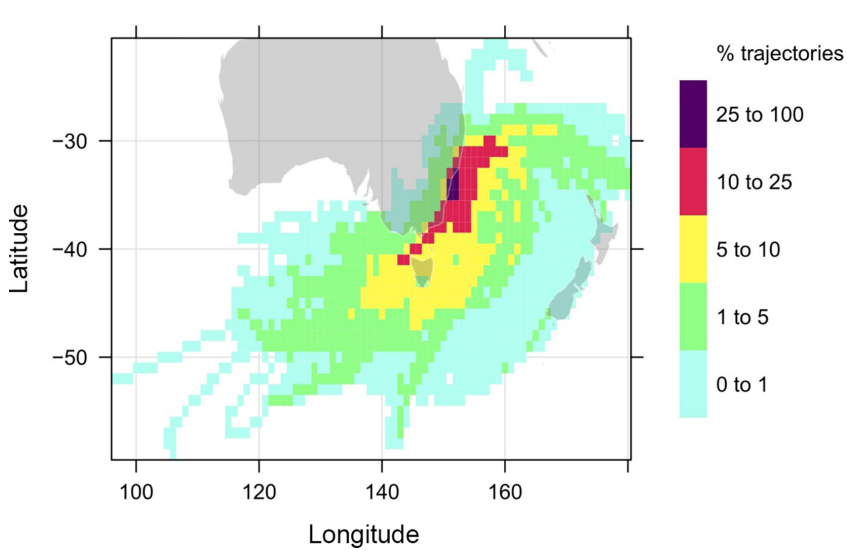

Figure 4. The 96-hour gridded back trajectory frequencies during MUMBA. The surface is coloured by the percentage of total trajectories which pass through each grid box.

\section{Urban, marine and biogenic influences during the MUMBA campaign}

The MUMBA campaign was designed to characterise the atmospheric composition at the ocean-forest-urban interface and thereby provide a dataset that could be used to test the skill of atmospheric models within a coastal environment. In this section, the major urban, marine and biogenic sources that influence the atmospheric composition in the region are described.

The dominant anthropogenic sources in the region are the Port Kembla steelworks, located approximately $10 \mathrm{~km}$ south of the main MUMBA site (for $\mathrm{PM}_{2.5}, \mathrm{PM}_{10}, \mathrm{CO}, \mathrm{NO}_{x}$ and $\mathrm{SO}_{2}$ ) and motor vehicles (for $\mathrm{NO}_{x}, \mathrm{CO}$ and VOCs) (http: //www.npi.gov.au/npidata). The ocean lies to the east of the site and large forested areas are to the west. Outflow from the Sydney basin ( $80 \mathrm{~km}$ to the north) may accompany winds from the northeast.

The impact of the different air masses sampled can be illustrated using a bivariate polar plot, which shows how a pollutant varies by wind speed and wind direction as sug- 

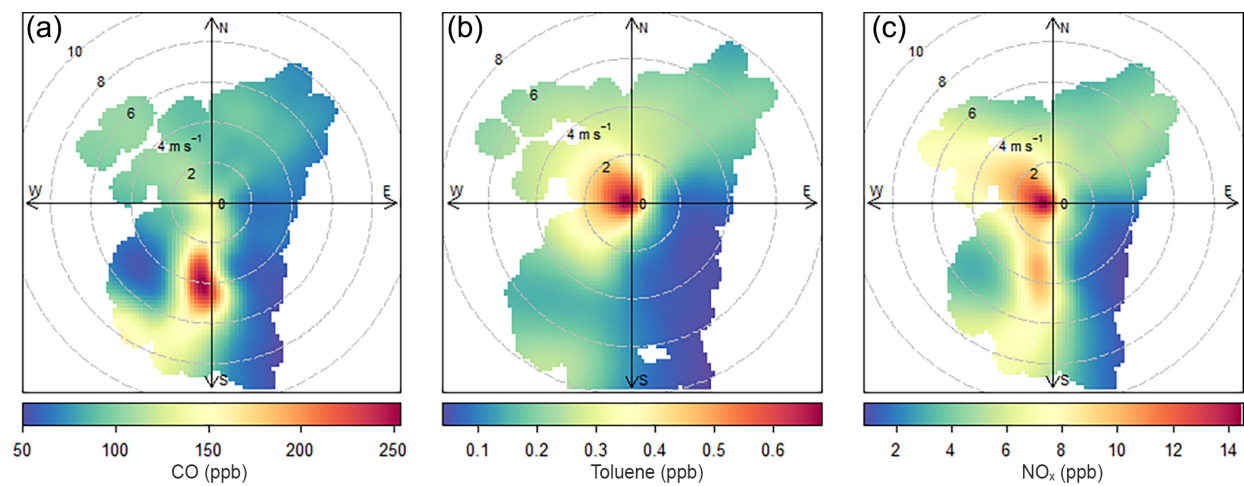

Figure 5. Bivariate polar plots showing how mole fractions (ppb) of (a) $\mathrm{CO}$, (b) toluene and (c) $\mathrm{NO}_{x}$ vary as a function of wind speed $\left(\mathrm{ms}^{-1}\right)$ and wind direction at the main MUMBA site during the campaign. Wind speed is represented by the concentric circles, and wind direction is shown as compass directions, such that the shape of the coloured area illustrates the wind speeds and directions experienced during the campaign. The colour indicates the mean mole fraction measured under the corresponding wind conditions.

gested by Carslaw et al. (2006). Figure 5a shows a bivariate polar plot for CO measured from the main MUMBA site throughout the campaign. Several distinct regions are evident, with the most obvious being the very high amounts of $\mathrm{CO}$ that are measured when the site experiences southerly winds with speeds between 2 and $6 \mathrm{~ms}^{-1}$. This direction brings air masses over central Wollongong and also over the industrial area centred on the steelworks at Port Kembla. In contrast, easterly to south-southeasterly winds bring very low amounts of $\mathrm{CO}$ to the MUMBA site as the air masses come from the Pacific Ocean. There were a number of occasions during the campaign when easterly winds brought predominantly marine air to the measurement site. These periods were identified by using radon values below a threshold of $200 \mathrm{mBq} \mathrm{m}^{-3}$, indicating minimal terrestrial impact in agreement with back trajectories. One episode in particular, on 26 December 2012, lasted several hours and was characterised by greenhouse gas concentrations similar to those measured in December 2012 at the Cape Grim baseline air pollution station on the northwest tip of Tasmania, Australia $\left(40.683^{\circ} \mathrm{S}, 144.689^{\circ} \mathrm{E}\right)$ (http://www.csiro.au/ greenhouse-gases/).

$\mathrm{CO}$ mole fractions from the northeast (that also come off the ocean) are nearly double those from the south-southeast, indicating that the MUMBA site may be influenced by outflow from the Sydney basin $80 \mathrm{~km}$ to the north. Elevated CO is also measured from the northwest in the direction of the nearest suburban shopping centre, multi-lane road and local industrial sites (including a cokeworks and mining operations). In contrast, relatively low concentrations are seen from the southwest where there is a steep escarpment and eucalypt forests beyond.

Figure $5 \mathrm{~b}$ shows the polar bivariate plot for toluene, which is predominantly emitted from motor vehicles and is not emitted from the steelworks. The plot shows the largest concentrations with low wind speeds, as is indicative of local sources building up in the nocturnal boundary layer; how- ever, there is a directional bias with much cleaner air to the east. This is due to clean marine air coming from the east and is also obvious in the low amounts of toluene coming from all wind speeds from the southeast. In contrast, there are slightly higher mole fractions of toluene that accompany winds from the northeast, again indicating possible outflow from Sydney or more local pollution to the north that is brought in on the sea breeze.

Figure $5 \mathrm{c}$ shows the polar bivariate plot for $\mathrm{NO}_{x}$, which shows a mixture of the features seen in the toluene and $\mathrm{CO}$ plots; this is indicative of a mixture of traffic and industrial sources as expected.

In Fig. 6, polar bivariate plots are shown for the main criteria pollutants of concern within the airshed $\left(\mathrm{PM}_{2.5}\right.$ and $\mathrm{O}_{3}$ ) along with the most significant biogenic volatile organic compounds, isoprene (PTR-MS $m / z$ 69) and monoterpenes (PTR-MS $m / z$ 137). Both isoprene and monoterpenes show very elevated concentrations with strong northwesterlies, which occurred on the two extremely hot days ( 8 and 18 January 2013). The monoterpenes are also high with still winds because (unlike isoprene) these compounds are also emitted during the night and hence build up in the nocturnal boundary layer. Also, under more stable nighttime conditions, katabatic flow down the escarpment will bring air predominantly influenced by the eucalypt forests to the site.

The highest $\mathrm{PM}_{2.5}$ concentrations are seen with strong to moderate winds from the south, which bring industrial sources from the Port Kembla steelworks. Elevated $\mathrm{PM}_{2.5}$ is also seen with northwesterly winds that bring biogenic influences from the escarpment and densely forested regions beyond. The highest $\mathrm{O}_{3}$ concentrations are also seen with the hot northwesterly winds, with the influence of $\mathrm{NO}_{x}$ titrating out the $\mathrm{O}_{3}$ clearly seen with low concentrations observed at low wind speeds and with wind from the south. The high $\mathrm{O}_{3}$ and $\mathrm{PM}_{2.5}$ values that accompany the high levels of isoprene and monoterpenes imply that biogenic influences are important for both $\mathrm{O}_{3}$ formation and secondary organic aerosol for- 

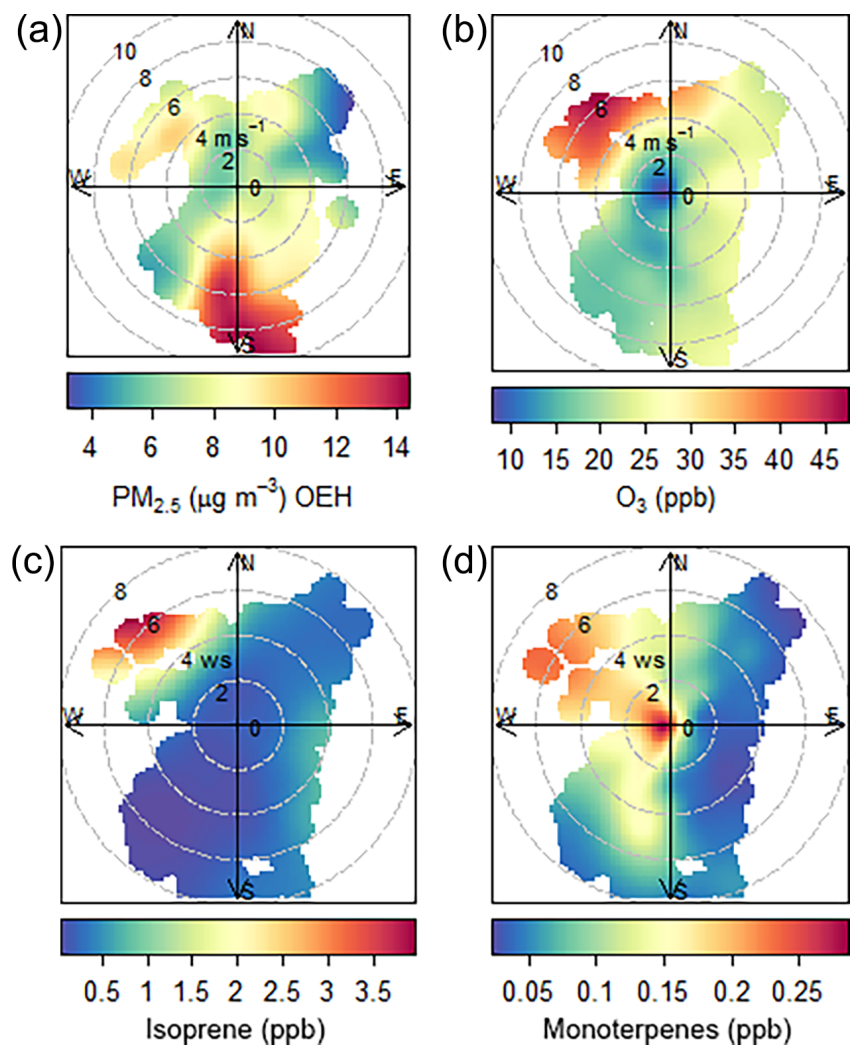

Figure 6. Bivariate polar plots showing how (a) the concentration of $\mathrm{PM}_{2.5}\left(\mu \mathrm{gm}^{-3}\right)$ at the $\mathrm{OEH}$ station and the mole fractions (ppb) of (b) $\mathrm{O}_{3}$, (c) isoprene and (d) monoterpenes at the main MUMBA site varied as a function of wind speed $\left(\mathrm{ms}^{-1}\right)$ and wind direction during the campaign.

mation in the region. This may be due to the VOC-limited environment (the formaldehyde-to- $\mathrm{NO}_{x}$ ratio averaged 0.3 over the campaign) coupled with the fact that anthropogenic emissions of VOCs are relatively low in the area, so that biogenic VOCs are extremely important to the overall budget. Despite the importance to air quality, biogenic emissions from Australian eucalypt forests are poorly understood (Emmerson et al., 2016), and further research is needed to better characterise biogenic emissions in this region of Australia.

\section{Data availability}

The data are available from PANGAEA (http://doi. pangaea.de/10.1594/PANGAEA.871982). The BOM Bellambi data discussed in this paper were publicly available on their website (http://www.bom.gov.au/climate/averages/ tables/cw_068228.shtml, accessed September 5th, 2014).

\section{Summary and conclusions}

The combined datasets from MUMBA provide a useful case study for testing the skill of air quality models in the complex environment of urban, marine and forest influences in coastal Australia, where the majority of its inhabitants live. This overview paper aims to provide the reader with a sufficient understanding of the MUMBA campaign to use the datasets as a test case for any air quality model, including an understanding of the Wollongong urban airshed, regional topography, emissions and meteorology.

During the 8 week campaign, the MUMBA site experienced some very different conditions, ranging from relatively polluted air (with local urban pollution from traffic and nearby industrial sources) to unpolluted marine air with a composition akin to that representative of the remote marine boundary layer measured at the Cape Grim station under baseline conditions. There were two extreme heat events during MUMBA when westerly winds brought strong biogenic influences from nearby forested regions. The measurements of the atmospheric composition during these events provide data that could prove to be a valuable test of models of future air quality in a changing climate.

A series of papers are in preparation that describe the main scientific findings from the MUMBA campaign, including articles focusing on (1) the drivers of urban air quality, (2) marine air at $34^{\circ} \mathrm{S}$, (3) biogenic emissions of volatile organic compounds, (4) the drivers of aerosol loading in the airshed and (5) new particle formation events. In addition, the MUMBA campaign measurements are being used in conjunction with long-term measurements from the OEH air quality network and campaign data from the Sydney Particle Study campaigns (Keywood et al., 2016a, b) as observational datasets in a modelling inter-comparison exercise involving four different regional air quality models. The MUMBA data are available from PANGAEA (https: //doi.pangaea.de/10.1594/PANGAEA.871982) for other researchers wanting to join the inter-comparison exercise or use the data independently to test atmospheric composition simulations in the region. 


\section{Appendix A: Details of the instruments used}

\section{A1 PTR-MS}

An Ionicon (Innsbruck, Austria) proton transfer reaction mass spectrometer (PTR-MS) from CSIRO operated throughout the MUMBA campaign. The PTR-MS was installed along with the auxiliary equipment that controls the flow rate and incorporates regular sampling of calibration gases and "zero air" (Galbally et al., 2007). The instrument performed zero measurements twice daily for $40 \mathrm{~min}$ each time (at 00:50 and 15:00 local time) by sampling ambient air that had been stripped of volatile organic compounds (VOCs) by passing through a platinum-coated glass wool catalyst heated to $350^{\circ} \mathrm{C}$. A multispecies, single-point calibration was performed daily (from 01:30 until 03:00 local time) by introducing a known flow of calibration standard into the zero air stream. Calibration mole fractions were $\sim 10$ to $20 \mathrm{ppb}$ for each VOC present in the standard.

The PTR-MS was operated using $\mathrm{H}_{3} \mathrm{O}^{+}$ions only and was programmed to scan through its range of mass-to-charge ratios $(m / z)$ with a dwell time of 1 second for a total cycle time of about 3 minutes. The mole fractions of volatile organic compounds were calculated from the PTR-MS at the following masses: formaldehyde (mass 31), methanol (mass 33 ), acetonitrile (mass 42), acetaldehyde (mass 45), acetone (mass 59), isoprene (mass 69), isoprene oxidation products methacrolein and methyl vinyl ketone (mass 71), benzene (mass 79), toluene (mass 93), xylenes (mass 107), trimethyl benzenes (mass 121) and monoterpenes (mass 137). Further details of these measurements, calibrations and corrections can be found in Guérette (2016).

\section{A2 VOC sequencer}

From 4 to 15 February 2013, continuous VOC measurements made using the PTR-MS were supplemented by integrated measurements collected on the VOC sequencer. The VOC sequencer passes air samples through two different adsorbent tubes to collect the VOCs and the carbonyls respectively. These tubes were analysed at CSIRO on a gas chromatography flame ionisation detection mass spectrometer (GC-FIDMS) for VOCs (Cheng et al., 2015) and HPLC for carbonyls (Lawson et al., 2015), which enables unambiguous species identification (this is not always provided by product ion mass numbers from the PTR-MS) at a 5, 8 or $10 \mathrm{~h}$ temporal resolution (Dunne et al., 2017). Unfortunately, there was a suspected leak on the VOC tube side (with very low concentrations measured), such that none of these data could be used. In addition, there were condensation issues for the carbonyl tubes and only a subset of the species could be determined with confidence. A list of the species measured successfully using the sequencer is given in Table B1.

\section{A3 Fourier transform infrared (FTIR) trace gas analysers}

FTIR trace gas analysers measure carbon dioxide $\left(\mathrm{CO}_{2}\right)$, methane $\left(\mathrm{CH}_{4}\right)$, carbon monoxide $(\mathrm{CO})$ and nitrous oxide $\left(\mathrm{N}_{2} \mathrm{O}\right)$ in air with precision and accuracy that meet the World Meteorological Organization Global Atmosphere Watch standards for baseline air. In addition, the instrument can measure ${ }^{13} \mathrm{C}$ in $\mathrm{CO}_{2}$ and retains the spectra, allowing post-analysis for other infrared active trace gases in highly polluted episodes (Kohlhepp et al., 2012). The instrument ran throughout the whole MUMBA campaign, with the only data interruption due to the cell temperature going above the range calibrated on 18 January 2013. In theory, the instrument could be retrospectively recalibrated at the higher temperatures, but since all other instruments had been switched off in the heat, this was not attempted. In addition to the instrument at the main MUMBA site, another FTIR trace gas analyser was operated throughout the campaign at the main campus of the University of Wollongong (Buchholz et al., 2016).

\section{A4 $\mathrm{NO}_{x}$ and $\mathrm{O}_{3}$ monitors}

Throughout the MUMBA campaign, $\mathrm{O}_{3}$ and $\mathrm{NO}_{x}$ measurements were made using monitors that utilised UV absorption and chemiluminescence techniques respectively. The NO- $\mathrm{NO}_{2}-\mathrm{NO}_{x}$ monitor (Thermo Scientific Instruments, Waltham, MA, USA; model TSI 42i-TL) detects NO using the chemiluminescence technique. $\mathrm{NO}_{2}$ is measured via decomposition to $\mathrm{NO}$ by passing over a molybdenum converter. The difference between the NO concentrations in the two samples is used to calculate the $\mathrm{NO}_{2}$ concentration. One issue with this technique is that other nitrates (such as PAN and $\mathrm{HNO}_{3}$ ) may be present and are also converted to NO by molybdenum but with different unknown efficiencies (Steinbacher et al., 2007). In order to get an indication of the likely level of this problem, a second $\mathrm{NO}_{x}$ monitor from CSIRO was deployed in the last 2 weeks of the campaign. This $\mathrm{NO}_{x}$ monitor uses a blue light converter so that only the $\mathrm{NO}_{2}$ is converted photolytically to NO (Fehsenfeld et al., 1990). The analysers were within $5 \%$ of each other for both $\mathrm{NO}$ and $\mathrm{NO}_{2}$.

\section{A5 Microphysical particle counters}

From 16 January to 15 February 2013, a suite of microphysical particle counters was operated at the main MUMBA site taking ambient air through an $8 \mathrm{~m}$ copper inlet mounted on the mast at a height of $\sim 9.5 \mathrm{~m}$ above the surrounding flat area.

An ultrafine condensation particle counter (uCPC; TSI model 3776) measured the total in situ number concentration of condensation nuclei $>3 \mathrm{~nm}$. Particles enter a supersaturated butanol chamber and all particles $>3 \mathrm{~nm}$ are grown to sizes able to be counted with a standard optical counter. 
A cloud condensation nuclei counter (CCNC) made by Droplet Measurement Technologies (Longmont, CO, USA) was used to measure the total number concentration of cloud condensation nuclei $(\mathrm{CCN})$. The instrument operates on a similar principle as the CPC, where aerosols are passed through a supersaturated chamber of liquid, except that water is used instead of butanol. Only particles able to act as CCN are thus activated and counted. The instrument was set up to measure particles activated at a supersaturation of $0.5 \%$.

The particle number size distribution from $\sim 14$ to $\sim 660 \mathrm{~nm}$ was measured with a scanning mobility particle sizer (SMPS). The SMPS (TSI model 3080 with DMA 3081 and TSI CPC 3772) ionises particles using radiation from $\mathrm{Kr}$ 85 decay. The charged particles then enter an electrostatic column which ramps its voltage to continually select particles based on their charge-mass ratio. Selected particles are then counted by a standard CPC.

Total $\mathrm{PM}_{2.5}$ aerosol mass concentration measurements were also made using a Met One E-sampler (Grants Pass, OR, USA) utilising laser scattering techniques (from 24 January to 15 February). The aerosol mass concentration is calibrated via the mass of an integrated sample collected on a filter that was changed weekly.

\section{A6 Filter samplers}

Filter samples of total $\mathrm{PM}_{2.5}$ aerosol were collected twice daily using an Ecotech high-volume air sampler (Knoxfield Victoria, Australia; HiVol). Integrated morning samples were collected on filters from 04:00 to 09:00 each day with integrated afternoon samples from 10:00 to 18:00 each day. Thus two filter changes were required (one between 09:00 and 10:00 and another after 18:00 and before 04:00). The filters were taken back to CSIRO for aerosol chemical composition analysis.

A small section $\left(\sim 0.5 \mathrm{~cm}^{2}\right)$ of each filter was punched out and the total collected $\mathrm{PM}_{2.5}$ aerosol analysed for its total carbon content, elemental carbon (EC) and organic carbon (OC) content using a thermal optical carbon analyser (model 2001A). The HiVol instrument logs the total flow of air that has been passed through each filter, so the total carbon, EC and $\mathrm{OC}$ in the integrated sample of air can be calculated in $\mu \mathrm{g} \mathrm{m}^{-3}$.

Also deployed was a streaker sampler from GNS Science (Lower Hutt, New Zealand). This sampler slowly rotates a disc holding two filters taking $\sim 48 \mathrm{~h}$ for a full revolution. The filters were changed every 2 days between 09:00 and 10:00. Only a small section of the filter is required for elemental composition analysis such that hourly measurements of black carbon and all elements from sodium to uranium on the periodic table are obtained.

\section{A7 LIDAR}

Throughout the MUMBA campaign, ANSTO provided a Leosphere ALS-400 (Orsay, France) cloud and aerosol LIDAR that measures elastic backscatter at $355 \mathrm{~nm}$, which is proportional to aerosol density. By plotting the (rangecorrected) backscatter against height, a vertical profile of aerosol density is created. A negative gradient in aerosol density as represented in the vertical profiles is indicative of a reduction in aerosol density and therefore a candidate for the boundary layer height. Boundary layer heights were estimated via two methods:

1. visually from plots of the logarithm of the rangecorrected $355 \mathrm{~nm}$ signal against height

2. and using the STRAT algorithm (Morille et al., 2007).

Since this technique relies on clear skies and sufficient aerosol loading to provide a strong backscatter signal, it is not always possible to determine the boundary layer height with confidence. Both estimates of boundary layer height with a $20 \mathrm{~min}$ resolution are included in the PANGAEA dataset (https://doi.pangaea.de/10.1594/PANGAEA. 871982).

\section{A8 Weather station}

Two different weather stations operated during MUMBA providing common meteorological parameters including temperature, humidity, pressure, wind speed and direction. The switch occurred on 25 January when the original (borrowed) weather station was needed for another field campaign. The Digitech system operated at a 5 min resolution and provided wind direction as 16 quadrants only, whereas the original station (Campbell Scientific Inc., Logan, UT, USA) operated at a $1 \mathrm{~min}$ resolution and provided wind direction with degree resolution. Both records are available on PANGAEA as hourly averages. 


\section{Appendix B: List of VOCs measured}

Table B1. List of VOCs.

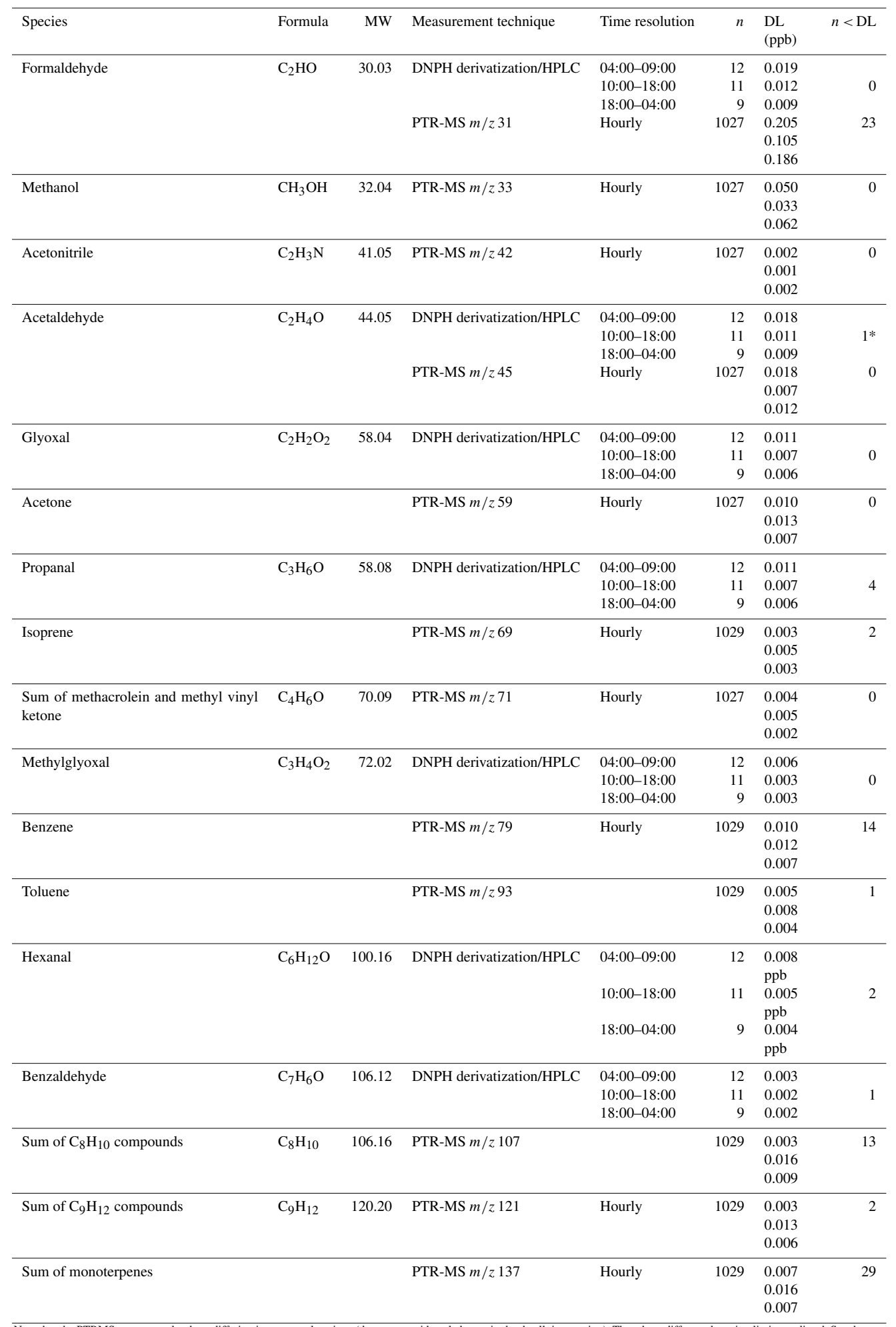


Competing interests. The authors declare that they have no conflict of interest.

Acknowledgements. The authors would like to thank all those from the University of Wollongong's Centre for Atmospheric Chemistry and CSIRO's Climate Science Centre group, who helped with the logistics of undertaking an extensive measurement campaign, in particular Travis Naylor, Graham Kettlewell, Christopher Caldow, Frances Phillips, Jason Ward, James Harnwell and Jenny Fisher. The ANSTO technical staff responsible for installing and maintaining the Warrawong radon detector were Ot Sisoutham and Sylvester Werczynski. Thanks are also due to Kids Uni and the Science Centre for their helpful support and to David Carslaw (and all the statisticians who developed the relevant " $R$ " code) for public access to the excellent openair package for the analysis of air quality data. We acknowledge funding from the Australian Research Council (for funding the campaign as part of the Discovery Project; DP110101948) and the Clean Air and Urban Landscapes Hub of Australia's National Environmental Science Programme (for funding the later analysis of the results that was required to produce this paper). This research was also supported by the Australian government Research Training Program (RTP) scholarships.

Edited by: G. M. R. Manzella

Reviewed by: two anonymous referees

\section{References}

Buchholz, R. R., Paton-Walsh, C., Griffith, D. W. T., Kubistin, D., Caldow, C., Fisher, J. A., Deutscher, N. M., Kettlewell, G., Riggenbach, M., Macatangay, R., Krummel, P. B., and Langenfelds, R. L.: Source and meteorological influences on air quality $\left(\mathrm{CO}, \mathrm{CH}_{4} \& \mathrm{CO}_{2}\right)$ at a Southern Hemisphere urban site, Atmos. Environ., 126, 274-289, https://doi.org/10.1016/j.atmosenv.2015.11.041, 2016.

Cainey, J. M., Keywood, M., Grose, M. R., Krummel, P., Galbally, I. E., Johnston, P., Gillett, R. W., Meyer, M., Fraser, P., Steele, P., Harvey, M., Kreher, K., Stein, T., Ibrahim, O., Ristovski, Z. D., Johnson, G., Fletcher, C. A., Bigg, E. K., and Gras, J. L.: Precursors to Particles (P2P) at Cape Grim 2006: campaign overview, Environ. Chem., 4, 143-150, https://doi.org/10.1071/en07041, 2007.

Carslaw, D. C. and Ropkins, K.: Openair - An r package for air quality data analysis, Environ. Modell. Softw., 27-28, 52-61, https://doi.org/10.1016/j.envsoft.2011.09.008, 2012

Carslaw, D. C., Beevers, S. D., Ropkins, K., and Bell, M. C.: Detecting and quantifying aircraft and other on-airport contributions to ambient nitrogen oxides in the vicinity of a large international airport, Atmos. Environ., 40, 5424-5434, doi:0.1016/j.atmosenv.2006.04.062, 2006.

Castro, L. M., Pio, C. A., Harrison, R. M., and Smith, D. J. T.: Carbonaceous aerosol in urban and rural European atmospheres: estimation of secondary organic carbon concentrations, Atmos. Environ., 33, 2771-2781, https://doi.org/10.1016/s13522310(98)00331-8, 1999.
Chambers, S., Williams, A. G., Zahorowski, W., Griffiths, A., and Crawford, J.: Separating remote fetch and local mixing influences on vertical radon measurements in the lower atmosphere, Tellus B, 63, 843-859, https://doi.org/10.1111/j.16000889.2011.00565.x, 2011.

Chambers, S. D., Williams, A. G., Crawford, J., and Griffiths, A. D.: On the use of radon for quantifying the effects of atmospheric stability on urban emissions, Atmos. Chem. Phys., 15, 1175-1190, https://doi.org/10.5194/acp-15-1175-2015, 2015.

Cheng, M., Galbally, I. E., Molloy, S. B., Selleck, P. W., Keywood, M. D., Lawson, S. J., Powell, J. C., Gillett, R. W., and Dunne, E.: Factors controlling volatile organic compounds in dwellings in Melbourne, Australia, Indoor Air, 26, 219-230, https://doi.org/10.1111/ina.12201, 2015.

Cheung, H. C., Morawska, L., and Ristovski, Z. D.: Observation of new particle formation in subtropical urban environment, Atmos. Chem. Phys., 11, 3823-3833, https://doi.org/10.5194/acp11-3823-2011, 2011.

Cheung, H. C., Morawska, L., Ristovski, Z. D., and Wainwright, D.: Influence of medium range transport of particles from nucleation burst on particle number concentration within the urban airshed, Atmos. Chem. Phys., 12, 4951-4962, https://doi.org/10.5194/acp-12-4951-2012, 2012.

Colomb, A., Gros, V., Alvain, S., Sarda-Esteve, R., Bonsang, B., Moulin, C., Klupfel, T., and Williams, J.: Variation of atmospheric volatile organic compounds over the Southern Indian Ocean (30-49 degrees S), Environ. Chem., 6, 70-82, https://doi.org/10.1071/en08072, 2009.

Cope, M. E., Hess, G. D., Lee, S., Tory, K., Azzi, M., Carras, J., Lilley, W., Manins, P. C., Nelson, P., Ng, L., Puri, K., Wong, N., Walsh, S., and Young, M.: The Australian Air Quality Forecasting System. Part I: Project description and early outcomes, J. Appl. Meteorol., 43, 649-662, https://doi.org/10.1175/2093.1, 2004.

Cope, M. E., Hess, G. D., Lee, S., Tory, K. J., Burgers, M., Dewundege, P., and Johnson, M.: The Australian Air Quality Forecasting System: Exploring first steps towards determining the limits of predictability for short-term ozone forecasting, Bound.Lay. Meteorol., 116, 363-384, https://doi.org/10.1007/s10546004-2816-2, 2005.

Dunne, E., Galbally, I. E., Cheng, M., Selleck, P., Molloy, S. B., and Lawson, S. J.: Comparison of VOC measurements made by PTR-MS, Adsorbent Tube/GC-FID-MS and DNPHderivatization/HPLC during the Sydney Particle Study, 2012: a contribution to the assessment of uncertainty in current atmospheric VOC measurements, Atmos. Meas. Tech. Discuss., https://doi.org/10.5194/amt-2016-349, in review, 2017.

Emmerson, K. M., Galbally, I. E., Guenther, A. B., Paton-Walsh, C., Guerette, E.-A., Cope, M. E., Keywood, M. D., Lawson, S. J., Molloy, S. B., Dunne, E., Thatcher, M., Karl, T., and Maleknia, S. D.: Current estimates of biogenic emissions from eucalypts uncertain for southeast Australia, Atmos. Chem. Phys., 16, 6997-7011, https://doi.org/10.5194/acp-16-6997-2016, 2016.

Fehsenfeld, F. C., Drummond, J. W., Roychowdhury, U. K., Galvin, P. J., Williams, E. J., Buhr, M. P., Parrish, D. D., Hübler, G., Langford, A. O., Calvert, J. G., Ridley, B. A., Grahek, F., Heikes, B. G., Kok, G. L., Shetter, J. D.,, Walega, J. G., Elsworth, C. M., Norton, R. B., Fahey, D. W., Murphy, P. C., Hovermale, C., Mohnen, V. A., Demerjian, K. 
L., and Mackay, G. I.: Intercomparison of $\mathrm{NO}_{2}$ Measurement Techniques, J. Geophys. Res.-Atmos., 95, 3579-3597, https://doi.org/10.1029/JD095iD04p03579, 1990.

Fletcher, C. A., Johnson, G. R., Ristovski, Z. D., and Harvey, M.: Hygroscopic and volatile properties of marine aerosol observed at Cape Grim during the P2P campaign, Environ. Chem., 4, 162171, https://doi.org/10.1071/en07011, 2007.

Galbally, I. E., Bentley, S. T., and Meyer, C. P.: Mid-latitude marine boundary-layer ozone destruction at visible sunrise observed at Cape Grim, Tasmania, 41 degrees 5, Geophys. Res. Lett., 27, 3841-3844, https://doi.org/10.1029/1999g1010943, 2000.

Galbally, I. E., Lawson, S. J., Weeks, I. A., Bentley, S. T., Gillett, R. W., Meyer, M., and Goldstein, A. H.: Volatile organic compounds in marine air at Cape Grim, Australia, Environ. Chem., 4, 178182, https://doi.org/10.1071/en07024, 2007.

Gray, H. A., Cass, G. R., and Huntzicker, J. J.: Characteristics of atmospheric organic and elemental carbon particle concentrations in Los Angeles, Environ. Sci. Technol., 20, 580-589, 1986.

Guérette, É.-A.: Measurements of volatile organic compound sources and ambient concentrations in south-east Australia, $\mathrm{PhD}$ Thesis, School of Chemistry, University of Wollongong, 2016.

Guérette, E.-A., Paton-Walsh, C., Kubistin, D., Humphries, R., Bhujel, M., Buchholz, R. R., Chambers, S., Cheng, M., Davy, P., Dominick, D., Galbally, I., Griffith, D. W. T., Griffiths, A., Keywood, M., Lawson, S., Molloy, S., Selleck, P., Simmons, J., and Wilson, S. R.: Measurements of Urban, Marine and Biogenic Air (MUMBA): characterisation of trace gases and aerosol at the urban, marine and biogenic interface in summer in Wollongong, Australia, https://doi.pangaea.de/10.1594/PANGAEA. 871982, 2017.

Hess, G. D., Tory, K. J., Cope, M. E., Lee, S., Puri, K., Manins, P. C., and Young, M.: The Australian Air Quality Forecasting System. Part II: Case study of a Sydney 7-day photochemical smog event, J. Appl. Meteorol., 43, 663-679, https://doi.org/10.1175/2094.1, 2004.

Hinwood, A. L., Rodriguez, C., Runnion, T., Farrar, D., Murray, F., Horton, A., Glass, D., Sheppeard, V., Edwards, J. W., Denison, L., Whitworth, T., Eiser, C., Bulsara, Mahesh, Gillett, R. W., Powell, J., Lawson, S., Weeks, I., and Galbally, I.: Risk factors for increased BTEX exposure in four Australian cities, Chemosphere, 66, 533-541, https://doi.org/10.1016/j.chemosphere.2006.05.040, 2007.

Husar, R. B., Liu, B. Y. H., and Whitby, K. T.: Physical Mechanisms Governing Dynamics of Los-Angeles Smog aerosol, J. Colloid Interf. Sci., 39, 211-224, https://doi.org/10.1016/00219797(72)90155-5, 1972.

Keywood, M., Cope, M., Meyer, C. P. M., Iinuma, Y., and Emmerson, K.: When smoke comes to town: The impact of biomass burning smoke on air quality, Atmos. Environ., 121, 13-21, https://doi.org/10.1016/j.atmosenv.2015.03.050, 2015.

Keywood, M., Selleck, P., Galbally, I., Lawson, S., Powell, J., Cheng, M., Gillett, R., Ward, J., Harnwell, J., Dunne, E., Boast, K., Reisen, F., Molloy, S., Griffiths, A., Chambers, S., Crumeyrolle, S., Zhang, C., Zeng, J., and Fedele, R.: Sydney Particle Study 1 - Aerosol and gas data collection. v3, edited by: CSIRO, https://doi.org/10.4225/08/57903B83D6A5D, 2016a.

Keywood, M., Selleck, P., Galbally, I., Lawson, S., Powell, J., Cheng, M., Gillett, R., Ward, J., Harnwell, J., Dunne, E., Boast, K., Reisen, F., Molloy, S., Griffiths, A., Chambers, S.,
Humphries, R., Guerette, E.-A., and Cohen, D.: Sydney Particle Study 2 - Aerosol and gas data collection. v1, edited by: CSIRO, https://doi.org/10.4225/08/5791B5528BD63, 2016b.

Kohlhepp, R., Ruhnke, R., Chipperfield, M. P., De Mazière, M., Notholt, J., Barthlott, S., Batchelor, R. L., Blatherwick, R. D., Blumenstock, Th., Coffey, M. T., Demoulin, P., Fast, H., Feng, W., Goldman, A., Griffith, D. W. T., Hamann, K., Hannigan, J. W., Hase, F., Jones, N. B., Kagawa, A., Kaiser, I., Kasai, Y., Kirner, O., Kouker, W., Lindenmaier, R., Mahieu, E., Mittermeier, R. L., Monge-Sanz, B., Morino, I., Murata, I., Nakajima, H., Palm, M., Paton-Walsh, C., Raffalski, U., Reddmann, Th., Rettinger, M., Rinsland, C. P., Rozanov, E., Schneider, M., Senten, C., Servais, C., Sinnhuber, B.-M., Smale, D., Strong, K., Sussmann, R., Taylor, J. R., Vanhaelewyn, G., Warneke, T., Whaley, C., Wiehle, M., and Wood, S. W.: Observed and simulated time evolution of $\mathrm{HCl}, \mathrm{ClONO}_{2}$, and $\mathrm{HF}$ total column abundances, Atmos. Chem. Phys., 12, 3527-3556, https://doi.org/10.5194/acp-12-3527-2012, 2012.

Lawson, S. J., Selleck, P. W., Galbally, I. E., Keywood, M. D., Harvey, M. J., Lerot, C., Helmig, D., and Ristovski, Z.: Seasonal in situ observations of glyoxal and methylglyoxal over the temperate oceans of the Southern Hemisphere, Atmos. Chem. Phys., 15, 223-240, https://doi.org/10.5194/acp-15-223-2015, 2015.

Modini, R. L., Ristovski, Z. D., Johnson, G. R., He, C., Surawski, N., Morawska, L., Suni, T., and Kulmala, M.: New particle formation and growth at a remote, sub-tropical coastal location, Atmos. Chem. Phys., 9, 7607-7621, https://doi.org/10.5194/acp-97607-2009, 2009.

Monks, P. S., Carpenter, L. J., Penkett, S. A., Ayers, G. P., Gillett, R. W., Galbally, I. E., and Meyer, C. P.: Fundamental ozone photochemistry in the remote marine boundary layer: The SOAPEX experiment, measurement and theory, Atmos. Environ., 32, 3647-3664, https://doi.org/10.1016/s13522310(98)00084-3, 1998.

Morille, Y., Haeffelin, M., Drobinski, P., and Pelon, J.: STRAT: An automated algorithm to retrieve the vertical structure of the atmosphere from single-channel lidar data, J. Atmos. Ocean. Tech., 24, 761-775, https://doi.org/10.1175/jtech2008.1, 2007.

Rea, G., Paton-Walsh, C., Turquety, S., Cope, M., and Griffith, D.: Impact of the New South Wales fires during October 2013 on regional air quality in eastern Australia, Atmos. Environ., 131, 150-163, https://doi.org/10.1016/j.atmosenv.2016.01.034, 2016.

Ristovski, Z. D., Suni, T., Kulmala, M., Boy, M., Meyer, N. K., Duplissy, J., Turnipseed, A., Morawska, L., and Baltensperger, U.: The role of sulphates and organic vapours in growth of newly formed particles in a eucalypt forest, Atmos. Chem. Phys., 10, 2919-2926, https://doi.org/10.5194/acp-10-2919-2010, 2010.

Steinbacher, M., Zellweger, C., Schwarzenbach, B., Bugmann, S., Buchmann, B., Ordonez, C., Prevot, A. S. H., and Hueglin, C.: Nitrogen oxide measurements at rural sites in Switzerland: Bias of conventional measurement techniques, J. Geophys. Res.Atmos., 112, D11307, https://doi.org/10.1029/2006jd007971, 2007.

Suni, T., Kulmala, M., Hirsikko, A., Bergman, T., Laakso, L., Aalto, P. P., Leuning, R., Cleugh, H., Zegelin, S., Hughes, D., van Gorsel, E., Kitchen, M., Vana, M., Hõrrak, U., Mirme, S., Mirme, A., Sevanto, S., Twining, J., and Tadros, C.: Formation and characteristics of ions and charged aerosol particles in a na- 
tive Australian Eucalypt forest, Atmos. Chem. Phys., 8, 129-139, https://doi.org/10.5194/acp-8-129-2008, 2008.

Tory, K. J., Cope, M. E., Hess, G. D., Lee, S., Puri, K., Manins, P. C., and Wong, N.: The Australian Air Quality Forecasting System. Part III: Case study of a Melbourne 4-day photochemical smog eventt, J. Appl. Meteorol., 43, 680-695, https://doi.org/10.1175/2092.1, 2004.

Turpin, B. J. and Huntzicker, J. J.: Identification of Secondary Organic Aerosol Episodes and Quantification of Primary and Secondary Organic Aerosol Concentrations During SCAQS, Atmos. Environ., 29, 3527-3544, https://doi.org/10.1016/13522310(94)00276-q, 1995.
Whitby, K. T., Husar, R. B., and Liu, B. Y. H.: The aerosol size distribution of Los Angeles smog, J. Colloid Interf. Sci., 39, 177204, 1972a.

Whitby, K. T., Liu, B. Y. H., Husar, R. B., and Barsic, N. J.: The minnesota aerosol-analyzing system used in the Los Angeles smog project, J. Colloid Interf. Sci., 39, 136-164, 1972b.

White, C. J. and Fox-Hughes, P.: Seasonal climate summary southern hemisphere (summer 2012-13): Austrlia's hottest summer on record and extreme east coast rainfall, Australian Meteorological and Oceanographic Journal, 63, 443-456, 2013. 